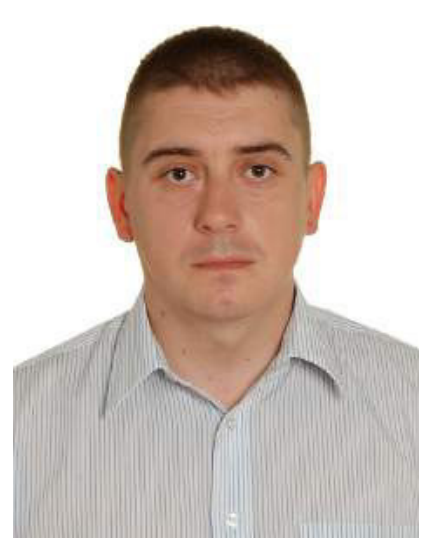

\author{
Ярослав Ільчишин, \\ начальник курсу, \\ Львівський державний університет безпеки \\ життєдіяльності \\ (м. Львів)
}

\author{
Yaroslav Ilchyshyn, \\ Head of the course, \\ Lviv State University of Life Safety \\ (Lviv) \\ ilchushun84@ukr.net
}

УдК 37.018.1(073)

\title{
ЕКСПЕРИМЕНТАЛЬНА ПЕРЕВІРКА ОРГАНІЗАЦІЙНО-ПЕДАГОГІЧНИХ УМОВ ВИХОВАННЯ ПРОФЕСІЙНОГО ОБОВ'ЯЗКУ МАЙБУТНІХ ФАХІВЦІВ ЦИВІЛЬНОГО ЗАХИСТУ
}

\section{EXPERIMENTAL EXAMINATION OF ORGANIZATIONAL AND PEDAGOGICAL CONDITIONS FOR PROFESSIONAL LIABILITY FOR THE FUTURE PROFESSIONALS OF CIVIL PROTECTION}

\begin{abstract}
Розроблено програму експериментального дослідження. Представлено схему організації дослідження. Визначено рівні готовності майбутніх фахівців цивільного захисту до виконання професійного обов'язку. Проаналізовано професійні якості майбутніх фахівців цивільного захисту. Встановлено компоненти готовності майбутніх фахівців цивільного захисту до виконання професійного обов'язку. Досліджено рівні готовності до виконання професійного обов'язку за мотиваційним, когнітивним, поведінковим критеріями. Зроблено висновок про ефективність організаційно-педагогічних умов виховання професійного обов'язку.
\end{abstract}

Ключові слова: професійний обов'язок, виховання, професійні якості, організаційно-педагогічні умови, експериментальне дослідження, майбутній фахівець цивільного захисту.

The program of experimental research is developed. The research organization chart is presented. The level of readiness of future specialists of civil defense to fulfill professional duty is determined. The professional qualities of future specialists of civil protection are analyzed. The components of readiness of future specialists of civil defense for fulfillment of professional duty are established. The level of readiness for fulfillment of professional duty by motivational, cognitive, and behavioral criteria is researched. One of the tasks of the study was to determine the actual level of formation of professional duties of future civil defense specialists. To fulfill this task, questionnaires, tests, questionnaires were developed; Control cuts; Statistical processing and analysis of the data received. During the experiment, the documentation on conducting educational events was analyzed. Charges and rewards statistics. The professional training of future specialists in civil protection will be carried out efficiently under the following organizational and pedagogical conditions: the creation of a training environment for an educational institution, the change of the role of the leader of the educator, the combination of collective and individual forms of training the professional duty of future civil defense specialists. The formative stage of experimental and experimental work involved an impact on cognitive, emotional and volitional spheres and the behavior of future specialists in civil defense. The use of active factors of influence (influence of environment and self-education) in working with cadets of experimental groups contributed to the growth of the level of formation of professional duty. A conclusion is made on the effectiveness of organizational and pedagogical conditions for the education of professional duties.

Key words: professional duty, education, professional qualities, organizational and pedagogical conditions, experimental research, future specialist of civil defense.

Разработана программа экспериментального исследования. Представлена схема организации исследования. Определены уровни готовности будущих специалистов гражданской защиты к выполнению профессионального долга. Проанализированы профессиональные качества будущих специалистов гражданской обороны. Установлено компоненты готовности будущих специалистов гражданской защиты к выполнению профессионального долга. Исследованы уровни готовности к выполнению профессионального долга по мотивационным, когнитивным, поведенческим критериям. Сделан вывод об эффективности организационно-педагогических условий воспитания профессионального долга.

Ключевые слова: профессиональный долг, воспитание, профессиональные качества, организационно-педагогические условия, экспериментальное исследование, будущий специалист гражданской защиты.

Постановка проблеми в загальному вигляді та їі зв'язок з важливими науковими та практичними завданнями. Сучасні зміни в організації кадрової політики служби надзвичайних ситуацій ставлять високі вимоги до якостей майбутніх фахівців цивільного захисту, які залучаються до роботи в зонах ліквідації наслідків природного і техногенного характеру. Вони повинні мати високий рівень професійної компетентності, бути здатними до рішення складних задач, приймати рішення і знаходити оптимальні шляхи для їх реалізації. Тому формування готовності 
майбутніх фахівців цивільного захисту до виконання професійного обов'язку є актуальним завданням вищих навчальних закладів. Особлива роль відводиться професійному вихованню майбутніх фахівців цивільного захисту, під час якого необхідність цілеспрямованої підготовки до виконання ними професійного обов'язку визнається провідною.

3 початком навчання у ВНЗ пов'язаний важливий етап професійного самовизначення, коли в майбутнього фахівця повинно виробитися позитивне ціннісне відношення до майбутньої професії. У цей період формується розуміння суспільної важливості професійної діяльності, осмислення професійного обов'язку [5, с. 213].

у зв'язку з цим можна констатувати наявність суперечності між потребою майбутніх фахівців цивільного захисту якісного виконання професійного обов'язку і відсутністю дієвих організаційно-педагогічних умов виховання професійного обов'язку.

Аналіз останніх досліджень і публікацій, у яких започатковано розв'язання проблеми. У Дослідженням проблем виховання професійних якостей майбутніх фахівців в різних галузях діяльності займалися багато вчених. Так, проблеми професійного виховання курсантів в умовах профільного вищого навчального закладу у своїх працях аналізували Ю. Антошків, Б. Білінський, В. Бут, В. Вареник, Г. Грибенюк, Л. Гонтаренко, А. Капля, М. Коваль, М. Козяр, Д. Лєбєдєв, С. Миронець, О. Парубок, В. Покалюк, Ю. Приходько, О. Склень, В. Шойко та ін.

У своїх роботах автори зосереджували увагу на підготовці курсантів військових навчальних закладів до виконання службового обов'язку. Утім, виховання готовності до виконання службових обов'язків майбутніх фахівців цивільного захисту, які також проходять професійну підготовку в умовах профільного вищого навчального закладу, не стали предметом спеціальних розвідок, що зумовлює актуальність досліджень у зазначеному руслі.

Формування мети статті. 3 огляду на вищезазначене метою даної статті є перевірка організаційно-педагогічних умов виховання професійного обов'язку майбутніх фахівців цивільного захисту.

Виклад основного матеріалу дослідження з повним обґрунтуванням отриманих наукових результатів. Державний Аналіз професійного обов'язку майбутніх фахівців цивільного захисту свідчить про наявність моральної та нормативної складової у його змісті. Вони інтегруються за принципом морального обґрунтування нормативних приписів. Правовий аспект професійного обов'язку повинен базуватися на моральних засадах. Значний вплив на професійний обов'язок має обов'язок суспільний, який є спільним для щодо будь-якої професійної діяльності. Суспільний обов'язок є категорією етики (деонтології), зумовлений нормами моралі, що існують в даному суспільстві, та визначається морально-вольовими якостями особистості. Його особливістює виконання особистістю обов'язку за власним бажанням, без примусу. Для певних професій, зокрема фахівців цивільного захисту, суспільний обов'язок має професійне забарвлення. Зміст професійного обов'язку не є однаковим, він може постійно змінюватися.

Аналіз програм професійної підготовки майбутніх фахівців цивільного захисту, матеріалів та програм виховних заходів, протоколів засідань вчених рад та рад студентського та курсантського самоврядування дозволяє зробити висновок про те, що в виховно-освітньому процесі $є$ певні розбіжності між метою, змістом та результатом готовності майбутніх фахівців цивільного захисту до виконання професійного обов'язку. На сьогоднішній день, навчальновиховний процес у ВНЗ спрямований на формування у курсантів та студентів професійних і спеціально-професійних компетентностей, а цільова установка на формування готовності майбутніх фахівців цивільного захисту до виконання професійного обов'язку практично відсутня, хоча певна робота в цьому напрямі проводиться.

Ми проаналізували організацію експериментальної роботи щодо формування професійних якостей майбутніх фахівців цивільного захисту. Т. Ткаченко експериментально перевіряв організаційно-педагогічні умови формування професійної компетентності курсантів засобами інформаційно-комунікаційних технологій. Зокрема, під час констатувального експерименту з'ясовано наявний рівень професійної компетентності, ефективність навчальної діяльності курсантів, недоліки організації навчально-виховного процесу та визначити шляхи їхнього усунення. Під час формувального експерименту це доведено ефективність запропонованої методики, надійність та вірогідність одержаних результатів [4, с. 12].

Під час організації та проведення дослідницької роботи А. Капля експериментально перевірив організаційнопедагогічні умови (забезпечення діяльнісно-особистісної основи соціалізації, демократизація курсантського середовища та гуманізація міжособистісних взаємин, проектування ситуацій соціального досвіду як аналога соціальних процесів та стимулювання процесів самовизначення, самореалізації та саморозвитку курсантів) соціалізації курсантів. На етапі формувального експерименту було доведено, що сучасний ВНЗ МНС України поступово стає „школою соціального досвіду”: метою навчального закладу такого типу є не лише формування системи знань, умінь і навичок, а й формування готовності курсантів до самовизначення в моральній, інтелектуальній, комунікативній, професійній сферах життєдіяльності, до саморозвитку індивідуальності кожного курсанта та самовиховання його як суб'єкта соціалізації [3, с.13].

У роботі Т. Ісаєнко виявлено й здійснено апробацію педагогічних умов: об'єктивних (зовнішніх) - програмних, професійних, культурологічних, а також суб'єктивних (внутрішніх) - когнітивних, емоційно-вольових, поведінкових. у ході експериментальної зроблено висновок, що особливе місце серед факторів формування військовопедагогічного середовища займає гуманізація та гуманітаризація системи військової освіти, що передбачає не тільки піднесення рівня і значення викладання гуманітарних дисциплін, а й формування в курсанта особливого ставлення до оточуючого світу та своєї діяльності в ньому [2, с. 14].

Навчально-виховна робота з формування готовності до професійної діяльності майбутнього офіцера пожежної охорони розглядається О. Биковою як феномен, який зумовлюється сукупністю морально-психологічної, 
командирської, креативної та комунікативної готовностей. 3 метою інтенсифікації формування готовності під час експериментальної роботи використовувалися загальні й індивідуальні заходи аудиторної і позааудиторної роботи, зокрема в наукових гуртках, безпосередньо на кафедрах, на спортивних майданчиках і полігонах [1, с. 11].

Спираючись на результати праць дослідників (О. Бикова, А. Капля, М. Коваль, М. Козяр, Т. Ткаченко та ін.), що вивчали питання формування професійних якостей курсантів та студентів у профільних ВНЗ, ми розробили програму експериментального дослідження організаційно-педагогічних умов виховання професійного обов'язку майбутніх фахівців цивільного захисту. Дослідження проводилося в три етапи (таблиця 1).

Основними методами оцінки готовності до виконання професійного обов'язку майбутніх фахівців цивільного захисту були: педагогічне спостереження; анкетування; аналіз робіт; експертна оцінка (в якості експертів виступають командири та педагоги, самі курсанти та студенти); самодіагностика (якісний опис і кількісна оцінка власних якостей); листи-спостережень, аналіз ситуацій, бесіди та інші методи якісного аналізу тощо.

Таблиця 1

\section{Схема організації дослідження}

\begin{tabular}{|c|c|c|}
\hline Етапи & Задачі етапу дослідження & Методи дослідження \\
\hline Дослідно-пошуковий & $\begin{array}{l}\text { Вивчалися наукова література, } \\
\text { навчально-методична } \\
\text { документація, педагогічний } \\
\text { досвід формування } \\
\text { професійного обов'язку } \\
\text { майбутніх фахівців цивільного } \\
\text { захисту, проводився аналіз } \\
\text { досліджень з даної проблеми, } \\
\text { розроблялися теоретичні } \\
\text { основи, гіпотеза, план та } \\
\text { програма експериментального } \\
\text { дослідження }\end{array}$ & $\begin{array}{l}\text { Аналіз, планування, порівняння, } \\
\text { діагностика }\end{array}$ \\
\hline $\begin{array}{l}\text { Проектно-експеримен- } \\
\text { тальний }\end{array}$ & $\begin{array}{l}\text { Продовжувалися теоретичні } \\
\text { та практичні дослідження; } \\
\text { проводилося дослідно- } \\
\text { експериментальне } \\
\text { дослідження; розроблялася } \\
\text { та апробувалася модель, } \\
\text { визначалися організаційно- } \\
\text { педагогічні умови формування } \\
\text { професійного обов'язку } \\
\text { майбутніх фахівців цивільного } \\
\text { захисту, здійснювалася } \\
\text { перевірка іх на практиці, } \\
\text { проводилось коригування } \\
\text { положень дослідження. }\end{array}$ & $\begin{array}{l}\text { Моделювання, проектування, } \\
\text { співставлення та коригування }\end{array}$ \\
\hline Підсумково-узагальню-ючий & $\begin{array}{l}\text { Проводилась статистична } \\
\text { обробка та унаочнення } \\
\text { отриманих даних, } \\
\text { аналізувалися результати } \\
\text { дослідно-експериментальної } \\
\text { роботи, формулювалися } \\
\text { висновки та визначалися } \\
\text { перспективи застосування }\end{array}$ & $\begin{array}{l}\text { Аналіз, оцінювання, } \\
\text { узагальнення, прогнозування }\end{array}$ \\
\hline
\end{tabular}

Для досягнення результатів діагностичного експерименту було визначено рівні готовності майбутніх фахівців цивільного захисту до виконання професійного обов'язку. Рівні (високий, середній та низький) визначалися експертами за допомогою спеціально розробленої системи критеріїв і оцінок.

Низький рівень характеризується пасивним ставленням до професійного обов'язку, несформованими ціннісними орієнтаціями, слабо вираженою усвідомленістю професійного обов'язку, епізодичною потребою проявляти професійні якості, низькою активністю у підвищенні рівня якостей до середнього і високого. Представників цієї групи вирізняють низькі показники орієнтації на морально-вольовий розвиток, нерозуміння професійного обов'язку та актуальності його формування в контексті майбутньої професійної діяльності. Ціннісні настанови потребують переорієнтації і корекції.

Середній рівень - характеризується сформованими ціннісними орієнтаціями, переконаннями, ідеалами, але чітка суспільна позиція - відсутня. Представників цієї групи мають певні знання щодо професійного обов'язку, але недостатнім $€$ усвідомлення сутності і призначення професійного обов'язку. Непостійними є потреба проявляти професійні якості та наміри підвищувати рівень якостей до високого.

Високий рівень - характеризують високі показники орієнтації на духовно-моральний розвиток і гуманність, усвідомлене розуміння сутності та змісту професійного обов'язку, виражену потребу проявити професійні якості, прагнення до їх удосконалення. представники даної групи професію обрали свідомо, керуючись своїми ціннісними настановами.

Одним із завдань нашого дослідження було визначення фактичного рівня сформованості професійного обов'язку майбутніх фахівців цивільного захисту. Для виконання цього завдання нами були розроблені анкети, тести, опитувальники; проведено контрольні зрізи; здійснено статистичну обробку та аналіз отриманих даних. 
Під час проведення експерименту ми аналізували документацію щодо проведення виховних заходів. статистику стягнень та заохочень.

На основі всебічного аналізу професійного обов'язку, згідно з процедурою дослідження визначено комплекс значущих професійних якостей майбутніх фахівців цивільного захисту, виявлена їх сутність та зміст за допомогою обґрунтованих критеріїв готовності майбутніх фахівців цивільного захисту до виконання професійного обов'язку (загальні якості професіонала, морально-вольові якості, якості спеціалізації, службово-посадові якості).

Таблиця 2

Критерії готовності майбутніх фахівців цивільного захисту до виконання професійного обов'язку

\begin{tabular}{|c|c|c|}
\hline & Професійні якості & Критерії професійних якостей \\
\hline \multirow{2}{*}{ 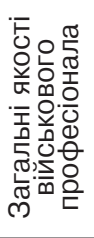 } & $\begin{array}{l}\text { Цілеспрямованість, } \\
\text { (пріоритет цілей, мотивів і дій, що } \\
\text { передбачають результат) }\end{array}$ & $\begin{array}{l}\text { Усвідомлення цілей майбутньої } \\
\text { діяльності, корисна активність у діях, } \\
\text { ініціатива, погоджені дії, прагнення до } \\
\text { успіху в роботі тощо }\end{array}$ \\
\hline & $\begin{array}{l}\text { Професійна активність } \\
\text { (ініціативна і зважена поведінка, } \\
\text { оперативний вплив на підлеглих) }\end{array}$ & $\begin{array}{l}\text { Ініціативні й впевнені дії, ревне } \\
\text { виконання обов'язків, прояв вольових } \\
\text { якостей, знань, умінь, навичок і } \\
\text { бажання досягти успіху }\end{array}$ \\
\hline \multirow{2}{*}{ 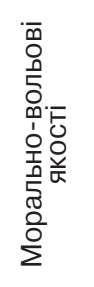 } & $\begin{array}{l}\text { Морально-психологічна стійкість } \\
\text { (активні, упевнені і наполегливі дії } \\
\text { в подоланні труднощів) }\end{array}$ & $\begin{array}{l}\text { Правильні поведінкові дії, уміле } \\
\text { сприйняття обстановки, зразкове } \\
\text { виконання обов'язків, домінування } \\
\text { позитивних емоцій, усвідомлене } \\
\text { самоврядування в складних ситуаціях }\end{array}$ \\
\hline & $\begin{array}{l}\text { Організаторські здібності } \\
\text { (уміння повести за собою людей, } \\
\text { активізувати їхню поведінку та дії) }\end{array}$ & $\begin{array}{l}\text { Упорядкованість своєї діяльності, чітка } \\
\text { взаємодія з підлеглими, погодженість } \\
\text { у роботі, внутрішня дисципліна, } \\
\text { мобілізація військовослужбовців в } \\
\text { особливих умовах діяльності }\end{array}$ \\
\hline \multirow{2}{*}{ 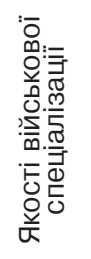 } & $\begin{array}{l}\text { Відповідальність (підвищене } \\
\text { почуття обов'язку за результати } \\
\text { своіх дій і дій підлеглих) }\end{array}$ & $\begin{array}{l}\text { Передбачення результатів своєї } \\
\text { діяльності, установка на виконання } \\
\text { завдань, самоконтроль за діями, } \\
\text { активність і ентузіазм у роботі, } \\
\text { прагнення до самовдосконалення }\end{array}$ \\
\hline & $\begin{array}{l}\text { Впевненість (корисні й активні дії } \\
\text { в особливих умовах діяльності) }\end{array}$ & $\begin{array}{l}\text { Уміння володіти собою, зразкова } \\
\text { поведінка, знання і розуміння } \\
\text { підлеглих, переконливість слів і дій, } \\
\text { упевнені дії в екстремальних ситуаціях }\end{array}$ \\
\hline \multirow{2}{*}{ 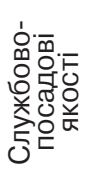 } & $\begin{array}{l}\text { Дисципллінованість, (своєчасна } \\
\text { адаптація, активнодіючий стан) }\end{array}$ & $\begin{array}{l}\text { Уміння переборювати труднощі, } \\
\text { повнота уявлень про діяльність та їі } \\
\text { виконання в особливих умовах }\end{array}$ \\
\hline & $\begin{array}{l}\text { Сумлінність (готовність до } \\
\text { дії, чіткість і організованість, } \\
\text { професіоналізм у роботі) }\end{array}$ & $\begin{array}{l}\text { Прагнення досягти поставленої мети, } \\
\text { сумлінне ставлення до обов'язків, } \\
\text { готовність до виконання функцій. }\end{array}$ \\
\hline
\end{tabular}

Виховання професійного обов'язку майбутніх фахівців цивільного захисту здійснюватиметься ефективно за таких організаційно-педагогічних умов: створення виховуючого середовища навчального закладу, зміна ролі командира вихователя, поєднання колективних та індивідуальних форм виховання професійного обов'язку майбутніх фахівців цивільного захисту.

3 метою визначення стану практики виховання майбутніх фахівців цивільного захисту було проведено констатувальний експеримент, в якому взяли участь 36 студентів та 29 курсантів першого курсу, 48 студентів та 50 курсантів другого курсу, 41 студенти та 54 курсантів третього курсу та 47 студентів та 63 курсантів четвертого курсу (всього 360 осіб) та формувальний, у якому взяли участь 320 курсантів (по 160 осіб у контрольній та експериментальній групах). Перевірка однорідності контрольної та експериментальної груп здійснювалася 3 використанням t-критерію Стьюдента. Перевірка нуль-гіпотези ( ) показала відсутність значних розбіжностей між вибірками для рівня достовірності 0,05 (вірогідність 5 \%).

Під час експерименту проводилось дослідження соціального, мотиваційного, освітнього, діяльнісного компонентів готовності майбутніх фахівців цивільного захисту до виконання професійного обов'язку

Як свідчать результати опитування, за період навчання збільшується кількість курсантів, які вважають себе готовими до виконання професійного обов'язку. Від першого до четвертого курсу стабільною є тенденція до зростання кількості курсантів, які вважають себе готовими до виконання професійного обов'язку. (від 23,47 \% курсантів першого курсу, 41,53 \% курсантів другого курсу, 43,27 \% курсантів третього курсу, 54,93 \% курсантів четвертого курсу). Водночас, спостерігалася тенденція до зменшення за період навчання кількості курсантів, які вважають, себе готовими до виконання професійного обов'язку. (від 74,18 \% курсантів першого курсу до 43,71 \% курсантів четвертого курсу). Пояснення такої ситуації було зроблено під час бесід з курсантами.

Формувальний етап дослідно-експериментальної роботи передбачав вплив на когнітивну, емоційно-вольову сфери та поведінку майбутніх фахівців цивільного захисту, що забезпечило б більш високий рівень готовності до 
виконання професійного обов'язку. Застосування активних чинників впливу (вплив середовища та самовиховання) у роботі з курсантами експериментальних груп сприяло зростанню рівня сформованості професійного обов'язку.

Оцінка рівня готовності до виконання професійного обов'язку за кожним критерієм (мотиваційним, когнітивним, поведінковим) у формі бесід, спостереження за поведінкою, анкетування, тестування та опитування.

Результати показали збільшення числа студентів з високим рівнем сформованості за поведінковим критерієм (15,63 \% - до початку дослідження і 36,25 \% - після його завершення).

Узагальнені результати перевірки за трьома критеріями та визначення їх динаміки у контрольних та експериментальних групах дали змогу зробити висновок про ефективність виховного впливу. В експериментальних групах зросла кількість курсантів з високим рівнем готовності до виконання професійного обов'язку (з 16,88 \% на початку експерименту до 26,25 \% після експерименту) та зменшилось число курсантів з низьким рівнем (з 39,37 \% на початку експерименту до 25 \% після експерименту). У контрольних групах ця тенденція виражена меншою мірою, істотних кількісних і якісних змін тут не відбулося.

Висновки і перспективи подальших досліджень. Результати формувального експерименту та їх порівняння з даними констатувального етапу дослідження дали змогу зафіксувати позитивну динаміку рівнів готовності до виконання професійного обов'язку, що свідчить про ефективність моделі та позитивний вплив запропонованих організаційно-педагогічних умов виховання професійного обов'язку майбутніх фахівців цивільного захисту. Перспективи подальшої роботи вбачаємо у вивченні можливостей екстраполяції набутого в результаті дослідження досвіду на інші спеціальності.

1. Бикова О. В. Формування готовності до професійної діяльності майбутніх офіцерів пожежної охорони; автореф. дис... канд. пед. наук: 13.00 .04 / О. В. Бикова.; Інститут педагогіки і психології професійної освіти АПН України - Київ, 2001.

2. Ісаєнко Т. К. Виховання моральної культури курсантів у педагогічному процесі вищих військових закладів освіти: автореф. дис... канд. пед. наук: 13.00.04 / Т.К. Ісаєнко; Харківський державний педагогічний університет ім. Г.С. Сковороди - Харків, 2005. . - 20 с

3. Капля А. М. Організаційно-педагогічні умови соціалізації курсантів у вищому навчальному закладі МНС України: автореф. дис... канд. пед. наук: 13.00 .05 / А. М. Капля; Національний педагогічний університет імені М.П. Драгоманова. - Київ, 2008. . - $21 \mathrm{c}$

4. Ткаченко Т. В. Формування професійної компетентності майбутніх фахівців безпеки життєдіяльності засобами інформаційно-комунікаційних технологій: автореф. дис... канд. пед. наук: 13.00.04 / Т. В. Ткаченко; Вінницький державний педагогічний університет імені Михайла Коцюбинського - Вінниця, 2009. . - 21 с

5. Цюприк А. Я. До проблеми розвитку професійного самовизначення майбутнього фахівця / А. Я. Цюприк, Т. Д. Якимович // Науковий вісник Південноукраїнського державного педагогічного університету ім. К. Ушинського : збірник наукових праць. - Одеса : ПДПУ ім. К. Ушинського, 2002. - Вип. 10. - Ч. ІІ. - С. 210-214.

\section{Reference}

1. Bykova O. V. Formuvannya hotovnosti do profesiynoyi diyal'nosti maybutnikh ofitseriv pozhezhnoyi okhorony; avtoref. dys... kand. ped. nauk: 13.00 .04 / O. V. Bykova.; Instytut pedahohiky i psykholohiyi profesiynoyi osvity APN Ukrayiny - Kyyiv, 2001. . - $20 \mathrm{~s}$

2. Isayenko T.K. Vykhovannya moral'noyi kul'tury kursantiv u pedahohichnomu protsesi vyshchykh viys'kovykh zakladiv osvity: avtoref. dys... kand. ped. nauk: 13.00.04 / T.K. Isayenko; Kharkivs'kyy derzhavnyy pedahohichnyy universytet im. H.S. Skovorody Kharkiv, 2005. . - $20 \mathrm{~s}$

3. Kaplya A. M. Orhanizatsiyno-pedahohichni umovy sotsializatsiyi kursantiv u vyshchomu navchal'nomu zakladi MNS Ukrayiny: avtoref. dys... kand. ped. nauk: 13.00.05 / A. M. Kaplya; Natsional'nyy pedahohichnyy universytet imeni M.P. Drahomanova. Kyyiv, 2008. . - $21 \mathrm{~s}$

4. Tkachenko T. V. Formuvannya profesiynoyi kompetentnosti maybutnikh fakhivtsiv bezpeky zhyttyediyal'nosti zasobamy informatsiyno-komunikatsiynykh tekhnolohiy: avtoref. dys... kand. ped. nauk: 13.00.04 / T. V. Tkachenko; Vinnyts'kyy derzhavnyy pedahohichnyy universytet imeni Mykhayla Kotsyubyns'koho - Vinnytsya, 2009. . - $21 \mathrm{~s}$

5. Tsyupryk A. YA. Do problemy rozvytku profesiynoho samovyznachennya maybutnoho fakhivtsya / A. YA. Tsyupryk, T. D. Yakymovych // Naukovyy visnyk Pivdennoukrayins'koho derzhavnoho pedahohichnoho universytetu im. K. Ushyns'koho : zbirnyk naukovykh prats'. - Odesa : PDPU im. K. Ushyns'koho, 2002. - Vyp. 10. - CH. II. - S. 210-214.

Рецензент І.М.Козловська, доктор педагогічних наук, Національний університет «Львівська політехніка» 